\title{
Psychosocial interventions for the diabetic patient
}

This article was published in the following Dove Press journal:

Diabetes, Metabolic Syndrome and Obesity: Targets and Therapy

9 January 2015

Number of times this article has been viewed

\section{John N Harvey}

Diabetes Research Group, Wrexham Academic Unit, Bangor University, Wrexham, UK
Correspondence: John $\mathrm{N}$ Harvey Gladstone Centre, Maelor Hospital, Wrexham LLI3 7TD, UK

Email john.harvey@wales.nhs.uk

\begin{abstract}
Diabetes usually requires substantial life-long self-management by the patient. Psychological factors and the patient's health beliefs are important determinants of self-care behavior. Education has a modest influence on generating better self-care, but psychologically based interventions are clearly more effective. This review gives an overview of these interventions with some discussion of their basis in psychological theory. Some labels such as cognitive behavioral therapy and family therapy include a wide range of approaches. Randomized trials have generally produced improvement in measures of psychological wellbeing, but improved glycemic control has been more elusive. The influence on behavior can be very dependent on the individual therapist. Only a few trials have managed to sustain improvement in glycosylated hemoglobin beyond a year. Not all patients are prepared to engage and accept these forms of therapeutic intervention. We are still some way from moving psychological management from the trial situation into the diabetic clinic.
\end{abstract}

Keywords: health beliefs, motivational interviewing, cognitive behavioral therapy, family therapy, adolescence

\section{Introduction}

Good glycemic control of diabetes leading to good long-term medical outcome requires a considerable degree of self-management by the patient. As clinicians we advise patients to undertake a series of self-management tasks: diet and exercise, regular therapy, injections, self-monitoring, self-adjustment of the treatment, and clinic visits. The motivation to undertake these behaviors can be limited in a condition where there is mostly little in the way of symptoms. Thus, psychological factors are important not only where there is psychopathology (pathological anxiety or fear, depression, eating disorder, and cognitive impairment) but more importantly as the factors that determine everyday "normal" behavior. Incomplete adherence to regimen is so common that it has to be considered normal behavior.

The diagnosis of diabetes has a major psychological impact. Adjustment of the individual to this psychological blow is critical. We need positive adjustment in which individuals accept the diagnosis and the need for lifestyle change. Patients need to adopt coping strategies that contribute positively to the management of their condition: adaptive coping behavior. A major challenge for health care professionals is to support and optimize adaptive coping behavior. The provision of education is important in that patients need to know what they need to do. However, many patients do know what to do but their adherence to the optimum regimen remains only partial. Clearly, knowledge alone does not determine behavior. Behavior is determined by health beliefs. 
Education can influence health beliefs. Indeed, understanding of the condition in its widest sense is a contributing factor to the model an individual carries of their condition. The way in which knowledge is delivered affects beliefs. However, in addition to education, we need specific behavioral change techniques aiming to alter patients' health beliefs. ${ }^{1}$ Meta-analysis of studies in young people with chronic illness indicates that psychologically based interventions generate better adherence to treatment than simple education (ie, provision of knowledge $)^{2}$ as did a trial in type 2 diabetes (T2DM). ${ }^{3}$ This article will discuss the interventions that have been used to influence self-care behavior in diabetes. Treatment for psychopathology is outside the scope of this review.

\section{Psychological theory}

Psychologists have devised numerous models to explain the relationship between patients' perceptions and their behavior. ${ }^{4}$ The health belief model postulates five main dimensions as the basis for behavior: perceived severity of the condition, susceptibility, perceived benefits/belief in treatment efficacy, costs/barriers, and cues to action. Self-regulatory theory (the common-sense model) posits that patients develop their own personal model of their condition. The personal model is made up of beliefs categorized under the headings of identity (symptoms and their meaning), causation including blame, timeline or course, seriousness or consequences, and curability or controllability, which includes perceptions of treatment effectiveness and personal control. On the basis of their personal model, patients adopt coping strategies that determine the outcome. Coping mechanisms may be adaptive, including acceptance, problem-focused coping, cognitive reappraisal, and seeking social support, or maladaptive such as avoidance or denial, expression of anger, or turning to alcohol or illegal drugs. There is a process of reassessment that leads people to adjust their beliefs and coping behavior in the light of their own experience. In parallel with an objective rational process, there is a similar process occurring at an emotional level in which patients develop coping behavior to manage their emotional perceptions.

An early review of interventions concluded that intervention should be based on theory. ${ }^{5}$ In this review, I shall summarize interventions as far as they can be categorized and try to relate them to theory.

\section{Methods}

In order to identify current work, a literature search strategy was devised. Medline and PsycInfo were searched using the terms "Diabet* and Psychosocial", "Diabet* and Cognitive
Behav*", "Diabet* and Motivat*", and "Diabet* and Family". This identified 177 references including 31 randomized controlled trials (RCTs) and eight major reviews. Recent systematic reviews were searched for further references. Those describing RCTs of interventions with a psychological component are included in a narrative review. I have referenced major reviews with the tables listing more recent trials. Number of subjects in trials listed in the text and tables refers to the total in intervention group(s) plus controls.

\section{Routine assessment}

Historically, psychological assessment has not featured significantly, if at all, in general diabetes management. However, the realization that adherence to recommended regimen is critical and very variable has led to the application of psychology to explain health-related behavior in psychologically normal patients. Symptoms (with the exception of hypoglycemia in some individuals) have little role in driving behavior in diabetes because patients with type 1 diabetes (T1DM) and T2DM are mostly symptom free. However, perceptions of seriousness, the effectiveness of treatment, and personal control do relate to behavior (and outcome) in diabetes. ${ }^{6}$ Emotional response is important as are social factors and family interactions. The seriousness of diabetes is often underplayed in routine diabetes education programs, but it is necessary that patients understand this: too many patients see their diabetes as not serious. To avoid generating fear, discussion of seriousness needs to be coupled with an emphasis on treatment effectiveness: "There are these serious complications but modern management is more effective than ever at preventing them if we work on this together". Fear is associated with maladaptive coping behaviors, poor control, and poor quality of life (QoL). Interventions need to assess these domains in individual patients.

In addition to clinical and biochemical assessments, QoL and other psychosocial measures are important goals of therapy. For these reasons some units have tried to make a psychosocial assessment a part of routine care. Self-completion patient questionnaires can be used. So the annual review might include a QoL questionnaire, assessment of problem areas (PAID questionnaire), recording of relevant life events, and discussion of the patient's agenda. Simple discussion of well-being can be helpful. In an RCT, patients were asked to fill out a computerized well-being questionnaire and then discuss the results with a diabetes nurse. This produced better mood and feelings of well-being, although no improvement in glycemic control. ${ }^{7}$ Clinicians need to retain a high index of suspicion for eating disorders, depression, 
and cognitive impairment, which are all the more common in diabetes and will affect diabetes management.

Group interventions are generally more cost-effective than individual consultations and have been used for decades in various psychiatric and psychological conditions. Group sessions usually focus on education, coping skills, behavioral skills, and interpersonal skills and not on more individual problems. Despite patients having differing socioeconomic backgrounds, previous experience, and personality, sharing their experience of the same medical condition is beneficial. This represents gaining social support at both the objective cognitive level and at the emotional level: adaptive coping behavior in the self-regulatory model. Common concerns to be dealt with might be fear of hypoglycemia, diet and weight issues, and risk of long-term complications. The therapist aims to reduce concern and improve perceptions of personal control and overall treatment effectiveness. A wide spectrum of approaches have been used in group sessions, from the purely educational to psychotherapy and including cognitive behavioral therapy (CBT), motivational interviewing (MI), and empowerment based programs.

\section{Motivational interviewing}

MI has become popular recently. First developed by Rollnick et al, the aim is to elicit the patient's own motivation to change behavior. Initial work was in the field of addiction. MI is now being used in a wide variety of chronic conditions. The counselor aims to evoke the patient's motivation to change through discussion of their own values, goals, and aspirations. ${ }^{8}$ The process moves through stages as proposed in the transtheoretical model of behavior change. ${ }^{9}$ Discussions are in a spirit of collaboration and respect the patient's autonomy to make decisions.

Meta-analysis of MI in various fields has shown psychologists and physicians to be more effective than other practitioners at delivering MI. Multiple sessions generated benefit. Overall, significant effects were seen on weight (body mass index), cholesterol, blood pressure, and alcohol consumption but not on smoking or glycosylated hemoglobin $\left(\mathrm{HbA}_{1 \mathrm{c}}\right) \cdot{ }^{10} \mathrm{MI}$ is effective at generating weight loss. ${ }^{11}$ More recent studies are given in Table $1 .{ }^{12-21}$ A relatively large recent study compared four sessions of MI over 2 months against four sessions of MI plus eight of CBT over 6 months (delivered by trained nurses) versus usual care. Twelve months later, the MI plus CBT group had mean $\mathrm{HbA}_{1 \mathrm{c}} 0.46 \%$ lower than the usual care group, but the MI group alone showed no improvement. ${ }^{22}$ Benefit was not sustained beyond 1 year. ${ }^{23}$
The DEPICTED study rolled out to routine clinics an approach based on MI delivered by training clinicians to use guiding and consultation skills in their routine practice. There was no effect on $\mathrm{HbA}_{1 \mathrm{c}} \cdot{ }^{15} \mathrm{CASCADE}$ was a large RCT in 26 clinics using nurses trained as educators to give education and intervention based on motivational interviewing techniques and a solution-based approach. It also failed to achieve an improvement in $\mathrm{HbA}_{1 \mathrm{c}} \cdot{ }^{16}$

\section{Empowerment}

Patients have to make their own decisions about their diabetes management day to day without professionals immediately at hand. Most patients need to make changes to their daily routine. The empowerment philosophy emphasizes that patients need the psychosocial skills to achieve behavior change, changes in their social situation, and other factors that influence their lives. Adults are much more likely to make and maintain behavior change if the change is personally meaningful and freely chosen. Thus, such change and solutions to barriers need to be elicited from the patient rather than directed by the professional. Professionals need to elicit and explore the emotional content of some diabetes problems that patients identify. Patients need to understand and accept that day-to-day care of their diabetes is their responsibility. It is necessary for patients to be viewed as full partners in the management process; otherwise, they will not express any disagreement with the professionals or list their own needs and values in relation to their diabetes management. Thus, we need to move to a patient-centered philosophy based on self-efficacy, self-management, and empowerment.

Patients may be asked about the difficulties of living with diabetes because the issues at the top of the list are those that can most readily be used to generate change. Discussion of feelings can motivate a patient. "How would this situation need to change for you to feel better about it?" How would the patient feel if things did not improve? These questions generate focus on what specifically needs to change. "What steps can you take? What are the difficulties/barriers? What single thing can you do next?" Behavior change protocols have been published previously. ${ }^{24} \mathrm{QoL}$ is better in patients who feel in control of their condition.

Anderson et al tested these principles in an $\mathrm{RCT}^{25}$ The program was designed to enhance appropriate goal setting, systematic problem solving to eliminate barriers to achieving set goals, cope with whatever cannot be changed, manage the stress of diabetes and general life, identify and obtain appropriate social support, and improve the ability to be self-motivated. Self-efficacy and attitude toward 
Table I Recent controlled trials of motivational interviewing in diabetes

\begin{tabular}{|c|c|c|c|c|}
\hline Reference & Numbers of subjects & $\begin{array}{l}\text { Type of } \\
\text { diabetes }\end{array}$ & $\begin{array}{l}\text { Age } \\
\text { of subjects }\end{array}$ & Format \\
\hline Viner et $\mathrm{al}^{12}$ & 41 & 1 & $1 \mathrm{I}-17$ years & $\begin{array}{l}\text { Pilot study with self-selected intervention } \\
\text { group. Weekly sessions for } 6 \text { weeks }\end{array}$ \\
\hline Channon et $\mathrm{al}^{13}$ & 80 & I & $14-17$ years & $\begin{array}{l}\text { MI (at home) vs support visits over } 12 \text { months. } \\
\text { Discussion of conflicting beliefs, alternative } \\
\text { behaviors, problem solving, goals, avoidance of } \\
\text { confrontation }\end{array}$ \\
\hline Nansel et al $^{14}$ & 81 & I & $11-16$ years & $\begin{array}{l}\text { Six individual sessions of } \mathrm{Ml} \text { over } 2 \text { months with } \\
\text { trainer. Phone contacts at } 6 \text { and } 12 \text { months }\end{array}$ \\
\hline $\begin{array}{l}\text { Robling et al } \\
\text { (DEPICTED) }^{15}\end{array}$ & 693 & I & $4-15$ years & Multicenter RCT of $\mathrm{MI}$ \\
\hline $\begin{array}{l}\text { Christie et al } \\
(\text { CASCADE })^{16}\end{array}$ & $\begin{array}{l}362 \text {, but } 47 \% \text { of the } \\
\text { intervention group did not } \\
\text { attend any sessions }\end{array}$ & I & $8-16$ years & $\begin{array}{l}\text { Solution-focused review and goal setting. } \\
\text { Enhancing motivation to change. Four group } \\
\text { sessions over } 4 \text { months }\end{array}$ \\
\hline West et $\mathrm{al}^{17}$ & 217 & $\begin{array}{l}2 \text {, female } \\
\text { patients }\end{array}$ & $\begin{array}{l}53 \pm 10 \text { (standard } \\
\text { deviation) years }\end{array}$ & $\begin{array}{l}42 \text { sessions, weekly for } 6 \text { months, biweekly } \\
\text { for } 6 \text { months then monthly }\end{array}$ \\
\hline Keogh et al ${ }^{18}$ & 121 & 2 & Mean age 59 years & $\begin{array}{l}\text { Three sessions of } \mathrm{Ml} \text { to patient } \\
\text { and family member }\end{array}$ \\
\hline $\begin{array}{l}\text { Gabbay et al } \\
\text { (DYNAMIC) }^{19}\end{array}$ & 545 & 2 & Adults & Ml-guided behavior change counseling \\
\hline Jansink et $\mathrm{al}^{20}$ & 940 & 2 & Up to age 80 years & $\begin{array}{l}\text { Structured care, reminders and feedback. } \\
\text { Lifestyle counseling based on MI }\end{array}$ \\
\hline Lakerveld et al ${ }^{21}$ & 502 at I year & 2 & Mean age 43.5 years & $\begin{array}{l}\text { Two group sessions to improve lifestyle and } \\
\text { reduce risk of diabetes and CV disease }\end{array}$ \\
\hline
\end{tabular}

Abbreviations: MI, motivational interviewing; QoL, quality of life; RCT, randomized controlled trial; CV, cardiovascular; $\mathrm{HbA}$, glycosylated hemoglobin.

diabetes improved. $\mathrm{HbA}_{1 \mathrm{c}}$ reduced $0.7 \%$ in the intervention group with no significant change in controls. Similarly, an empowerment-based program for patients with T2DM improved QoL and glycemic control by $0.7 \%$ at 6 months (compared with a much smaller nonsignificant reduction in controls). The sessions addressed goal setting, problem solving, coping with diabetes and stress, seeking social support, and staying motivated. ${ }^{26}$ A 6-week Spanish language program based on self-efficacy theory generated behavioral benefits. ${ }^{27}$ A program of six sessions held weekly followed by monthly support group meetings until 12 months all based on an empowerment approach showed that improvements in $\mathrm{HbA}_{1 \mathrm{c}}$ $(-0.5 \%)$ were sustained over 3 years. ${ }^{28}$ However, in African Americans with T2DM, weekly group sessions over 6 months to deliver an empowerment-based self-management program generated no benefits. ${ }^{29}$

With insulin-treated patients, training to adjust their own insulin dose for meal size, fasting, or correction of hyperglycemia produced better glycemic control as expected but also generated greater perceptions of self-efficacy and a feeling of empowerment. ${ }^{30}$ But a 6-week empowerment program for teenagers generated no significant difference in empowerment or $\mathrm{HbA}_{1 \mathrm{c}}$ at 24 months. ${ }^{31}$ Effects may be more difficult to sustain over time in young people.

Research using self-regulatory theory indicates that personal control is an important part of the patient's personal model of their diabetes. Personal control relates to glycemic control. ${ }^{6}$ Empowerment increases the individual's personal control and is therefore consistent with theory.

\section{Cognitive behavioral therapy}

Behaviorist methods reward appropriate behavior and "punish" poor behavior. Reward generates reinforcement. The patient is passive, the therapist is active and in control. Underlying thoughts are not considered even though they may be persistent determinants of behavior. In contrast, 


\begin{tabular}{|c|c|c|c|c|}
\hline \multirow{2}{*}{$\begin{array}{l}\text { Program } \\
\text { delivered by }\end{array}$} & \multirow{2}{*}{$\begin{array}{l}\text { Duration } \\
\text { of follow-up }\end{array}$} & \multicolumn{3}{|l|}{ Outcomes } \\
\hline & & Coping behaviors & Psychological well-being & Glycemic control \\
\hline Therapist & 12 months & Self-efficacy improved & $\begin{array}{l}\text { Psychological distress was } \\
\text { unchanged }\end{array}$ & $\begin{array}{l}\mathrm{HbA} \text { Ic reduced by I.5\% at } \\
4-6 \text { months }(P<0.05) \text {. } \\
\text { The difference at } 12 \text { months was } \\
\text { not quite significant }(P<0.06)\end{array}$ \\
\hline Trainee health psychologist & 2 years & $\begin{array}{l}\text { No improvement in } \\
\text { locus of control, self- } \\
\text { efficacy, or knowledge }\end{array}$ & $\begin{array}{l}\text { Better QoL, less worry, and } \\
\text { anxiety. Increased perception } \\
\text { of seriousness with greater } \\
\text { emphasis on control }\end{array}$ & $\begin{array}{l}\mathrm{HbA}_{\mathrm{lc}} \text { reduced by } 0.6 \% \text { vs increase } \\
\text { in controls }(P=0.003)\end{array}$ \\
\hline $\begin{array}{l}\text { Non-professional graduates } \\
\text { with } 80 \text {-h training in } \mathrm{Ml}\end{array}$ & 2 years & & & $\begin{array}{l}\mathrm{HbA} A_{\mathrm{Ic}} \text { improved: } 8.43 \% \text { vs } 8.93 \% \\
(P=0.05) \text {. Greater effect in older } \\
\text { youths }\end{array}$ \\
\hline Trained research nurses & 12 months & $\begin{array}{l}\text { Short-term ability } \\
\text { to cope with diabetes } \\
\text { improved }\end{array}$ & No improvement in well-being & No effect on $\mathrm{HbA}_{\mathrm{Ic}}$ \\
\hline $\begin{array}{l}\text { Pediatric diabetes nurses } \\
\text { having undergone two } \\
\text { training workshops }\end{array}$ & 2 years & & $\begin{array}{l}\text { Attenders reported improved } \\
\text { family relationships, knowledge, } \\
\text { understanding, confidence, and } \\
\text { motivation }\end{array}$ & $\begin{array}{l}\text { No improvement in } \mathrm{HbA}_{\mathrm{Ic}} \text { at } \mathrm{I} 2 \text { or } \\
24 \text { months }\end{array}$ \\
\hline $\begin{array}{l}\text { Behaviorist, nutritionist, } \\
\text { exercise physiologist, and } \\
\text { diabetes educator }\end{array}$ & 18 months & $\begin{array}{l}\text { Enhanced adherence } \\
\text { to behavioral weight } \\
\text { loss program }\end{array}$ & & $\begin{array}{l}\text { More weight loss with } \mathrm{Ml} \text { at } 6 \\
(P=0.0 \mathrm{I}) \text { and } \mathrm{I} 8 \text { months }(P=0.04) \text {. } \\
\mathrm{HbA}_{\mathrm{Ic}} \text { better at } 6 \text { months }(P=0.02) \\
\text { but not at } \mathrm{I} 8 \text { months }\end{array}$ \\
\hline Therapist & 6 months & $\begin{array}{l}\text { Improved diet, } \\
\text { exercise, and family } \\
\text { support }\end{array}$ & $\begin{array}{l}\text { Improved beliefs about diabetes } \\
\text { and well-being }\end{array}$ & $\begin{array}{l}\text { HbA } A_{1 c} \text { reduced: } 8.4 \% \text { vs } 8.8 \% \\
(P=0.04)\end{array}$ \\
\hline Nurses trained in $\mathrm{Ml}$ & 2 years & & $\begin{array}{l}\text { Intervention improved } \\
\text { depression scores }\end{array}$ & No better than usual care \\
\hline Trained nurses & 14 months & $\begin{array}{l}\text { No improvement in } \\
\text { diet or physical activity }\end{array}$ & No improvement in QoL & No improvement in $\mathrm{HbA}_{\mathrm{lc}}$ \\
\hline Trained nurses & I years & $\begin{array}{l}\text { No improvement } \\
\text { in lifestyle behavior }\end{array}$ & & No reduction in diabetes or $\mathrm{CV}$ risk \\
\hline
\end{tabular}

CBT explores negative beliefs that generate negative conclusions, anxiety, depression, and guilt. CBT holds that thoughts and attitudes determine a person's mood rather than external events. The treatment involves challenging negative thoughts and has been used to alter behavior and to treat mood disorders. The patient and therapist work collaboratively. Patients must be motivated to change, which in turn is dependent upon their beliefs about seriousness, consequences, etc. Group sessions based on CBT address problem-solving and coping skills, cognitive restructuring, and stress management.

In an early study, a cognitive behavioral intervention was delivered to groups of adults by mental health professionals, in which individuals identified their own barriers to selfcare with a problem-solving orientation being developed. Relevant thoughts and attitudes were identified to generate a positive approach. The groups practiced coping skills to deal with problems in regimen adherence, finishing with an agreed contract for changes in self-care and training in relapse prevention. At 6 months and 12 months, knowledge, self-efficacy, and self-esteem had increased and anxiety and depression scores had reduced. More self-monitoring of blood glucose and exercise was being undertaken and $\mathrm{HbA}_{1 \mathrm{c}}$ was lower: $9.5 \%$ vs $11.5 \%(P<0.001) .{ }^{32}$ Others have also delivered CBT to groups (Table 2).${ }^{33-39}$ A pilot study of four weeks of group CBT for T1DM patients in poor control helped them overcome negative beliefs and attitudes toward diabetes, generating improved self-care behavior. Compared with baseline, $\mathrm{HbA}_{1 \mathrm{c}}$ was $0.8 \%$ lower at 6 months. ${ }^{40}$ However, in the subsequent RCT of the program extended to six of the weekly sessions, there was no improvement in $\mathrm{HbA}_{1 \mathrm{c}}$, although self-efficacy, diabetes-related distress, and mood improved, illustrating the importance of undertaking wellcontrolled RCTs in this area. ${ }^{33} \mathrm{CBT}$ was effective in combination with MI. ${ }^{22}$ The practical application of CBT in children has been reviewed. ${ }^{41}$ 
Table 2 Recent controlled trials of CBT in diabetes

\begin{tabular}{|c|c|c|c|c|}
\hline Reference & $\begin{array}{l}\text { Numbers } \\
\text { of subjects }\end{array}$ & $\begin{array}{l}\text { Type of } \\
\text { diabetes }\end{array}$ & $\begin{array}{l}\text { Age } \\
\text { of subjects }\end{array}$ & Format \\
\hline van der Ven et $\mathrm{al}^{33}$ & 88 & I & $20-60$ years & $\begin{array}{l}\text { Group CBT: cognitive restructuring and } \\
\text { individual goal setting. Six } 2 \mathrm{~h} \text { weekly sessions }\end{array}$ \\
\hline Snoek et $\mathrm{al}^{34}$ & 86 & I & Adults & Six weekly group sessions of CBT or BGAT \\
\hline Amsberg et $\mathrm{al}^{35}$ & 94 & I & Adults & $\begin{array}{l}\text { Eight weekly 2-h group sessions. CGMS for } \\
\text { biofeedback. Structured maintenance program } \\
\text { over weeks } 9-48\end{array}$ \\
\hline Lehmkuhl et al"'I & 32 & I & Child-parent dyads & Telehealth behavior therapy \\
\hline $\begin{array}{l}\text { Ismail et } \mathrm{al}^{22} \\
\text { Ridge et } \mathrm{al}^{23}\end{array}$ & $\begin{array}{l}344,260 \text { completed } \\
\text { long-term follow-up }\end{array}$ & I & $18-65$ years & $\begin{array}{l}\text { Four sessions of MET vs } 4 \text { sessions MET + } \\
8 \text { sessions CBT vs usual care }\end{array}$ \\
\hline Karlsen et $\mathrm{al}^{36}$ & 63 & I and 2 & $25-70$ years & $\begin{array}{l}\text { Group CBT: cognitive restructuring and } \\
\text { problem solving vs waiting list controls }\end{array}$ \\
\hline Gregg et $\mathrm{a}^{37}$ & 81 & 2 & Adults & 7-h education vs 4 -h education $+3 \mathrm{~h}$ ACT \\
\hline Forlani et al ${ }^{38}$ & 822 & 2 & Adults & $\begin{array}{l}\text { 12-15 group sessions CBT }(2 \text { h) vs } 4 \text { sessions } \\
\text { diet education vs simple prescriptive diet }\end{array}$ \\
\hline Welschen et a ${ }^{39}$ & 154 & 2 & $18-75$ years & $\begin{array}{l}\text { Intervention group received } 3-6 \text { CBT sessions } \\
\text { each } 30 \mathrm{~min}\end{array}$ \\
\hline
\end{tabular}

Abbreviations: ACT, acceptance and commitment therapy; BGAT, blood glucose awareness training; CBT, cognitive behavioral therapy; CGMS, continuous glucose monitoring system; MET, motivational enhancement; $\mathrm{HbA}_{1 \mathrm{c}}$, glycosylated hemoglobin; QoL, quality of life.

Surwit et al found stress management improved $\mathrm{HbA}_{1 \mathrm{c}}$ $0.5 \% .{ }^{42} \mathrm{~A}$ recent development is Acceptance and Commitment therapy, which involves the patient accepting what is outside their personal control but committing to action to create a rich and meaningful life while accepting the problems. The intention is that adaptive behavioral response can take place alongside emotional response. Mindfulness refers to a focus on the here and now. Problem thoughts are considered as "Are thoughts helpful?" not "Are they true?" Thus, where behavioral therapy and CBT aim to reduce distressing thoughts, Acceptance and Commitment Therapy accepts these thoughts and works round them. In a 3-month RCT, the treatment group received mindfulness and acceptance training regarding difficult thoughts and feelings about diabetes, exploration of personal values related to diabetes, and a focus on the ability to act in a valued direction during difficult experiences. At the end of 3 months, $\mathrm{HbA}_{1 \mathrm{c}}$ reduced slightly from $8.21 \%$ to $8.07 \%$ in the control group but from $8.17 \%$ to $7.47 \%$ in the Acceptance and Commitment Therapy group $(P=0.009) .{ }^{37}$

\section{Family interventions in adults}

Interventions that involve the family are logical since this is the patient's own familiar environment. Family therapy, defined as intervention where any family member is actively involved in the treatment program, has been used in patients of all ages with T1DM and T2DM. The majority of studies in adults have compared patient education with education for patient and partner together. In T1DM, involving the partner improved $\mathrm{HbA}_{1 \mathrm{c}}{ }^{43,44}$ In T2DM, Wing et al did not find an overall benefit from spousal support on $\mathrm{HbA}_{1 \mathrm{c}}$ or weight, but there was a sex difference. Women did better when their spouses were involved in the program. The converse was true with men, who did better when their partners were not involved in the intervention. ${ }^{45} \mathrm{~A}$ trial in Chile found that family counseling, family meetings, and home visits improved $\mathrm{HbA}_{1 \mathrm{c}}{ }^{46}$ whereas an RCT in Taiwan found that a similar program improved behavior, knowledge, and attitudes but not glycemic control. ${ }^{47}$

The majority of family intervention studies have been conducted with children and adolescents.

\section{Type I diabetes in children and adolescents}

Most of the techniques listed in this review have been used in children and adolescents. Young people with diabetes should undergo psychological assessment when glycemic control is poor for no clear reason, there are frequent hospital 


\begin{tabular}{|c|c|c|c|c|}
\hline \multirow{2}{*}{$\begin{array}{l}\text { Program } \\
\text { delivered by }\end{array}$} & \multirow{2}{*}{$\begin{array}{l}\text { Duration } \\
\text { of follow-up }\end{array}$} & \multicolumn{3}{|l|}{ Outcomes } \\
\hline & & Coping behaviors & Psychological well-being & Glycemic control \\
\hline $\begin{array}{l}\text { Diabetes nurse and } \\
\text { psychologist together }\end{array}$ & 3 months & $\begin{array}{l}\text { Self-efficacy and self-care } \\
\text { behavior improved }\end{array}$ & $\begin{array}{l}\text { Diabetes distress and mood } \\
\text { improved }\end{array}$ & No improvement in $\mathrm{HbA}_{\mathrm{Ic}}$ \\
\hline $\begin{array}{l}\text { Diabetes nurse educator } \\
\text { and psychologist together }\end{array}$ & 12 months & $\begin{array}{l}\text { More insulin dose self- } \\
\text { adjustment in both groups }\end{array}$ & $\begin{array}{l}\text { Both interventions lowered } \\
\text { depression scores }\end{array}$ & No difference in $\mathrm{HbA}_{\mathrm{lc}}$ \\
\hline $\begin{array}{l}\text { Diabetes nurse and } \\
\text { psychologist (trained in } \\
\text { CBT) together }\end{array}$ & 48 weeks & $\begin{array}{l}\text { Self-monitoring of blood } \\
\text { glucose frequency } P<0.05 \text {. } \\
\text { More avoidance of hypoglycemia }\end{array}$ & $\begin{array}{l}\text { Well-being, stress, anxiety, } \\
\text { and depression improved: } \\
\text { each } P<0.05 \text {. Distress } P<0.0 \text { I }\end{array}$ & $\begin{array}{l}\mathrm{HbA}_{\text {Ic }} \text { improved }(P<0.05) \text {. } \\
\text { More mild hypoglycemia } \\
\text { with CBT }\end{array}$ \\
\hline Via web link & 12 weeks & & $\begin{array}{l}\text { Youth perceptions of their } \\
\text { behavior improved }\end{array}$ & \\
\hline Nurse delivered & 4 years & No improvement & No improvement & $\begin{array}{l}\text { MET }+ \text { CBT better at I year } \\
\left(\mathrm{HbA}_{\mathrm{lc}}-0.46 \%\right) \text { but not at } 2 \text {, } \\
3 \text {, and } 4 \text { years }\end{array}$ \\
\hline Nurses & 6 months & $\begin{array}{l}\text { Problem-focused and emotion- } \\
\text { focused coping did not improve }\end{array}$ & $\begin{array}{l}\text { Diabetes stress and self-blame } \\
\text { reduced. Well-being did not } \\
\text { improve }\end{array}$ & \\
\hline Psychologist & 3 months & $\begin{array}{l}\text { Increased use of acceptance } \\
\text { and mindfulness coping and } \\
\text { better diabetes self-care }\end{array}$ & & $\begin{array}{l}\text { Greater } \mathrm{HbA}_{\mathrm{lc}} \text { reduction with } \\
\text { ACT } P=0.009\end{array}$ \\
\hline $\begin{array}{l}\text { Two sessions given } \\
\text { by psychologist }\end{array}$ & 4 years & & & $\begin{array}{l}\text { Significant weight loss, better } \\
\text { glycemic control, and less need } \\
\text { for insulin in both structured } \\
\text { programs }\end{array}$ \\
\hline Nurses and dietitians & $6-12$ months & Physical activity increased & QoL and depression improved & No improvement in $\mathrm{HbA}_{\mathrm{Ic}}$ \\
\hline
\end{tabular}

admissions, problems at school, or obvious psychological distress. Teenage girls often miss insulin injections to try and lose weight. It is suggested that up to $25 \%$ of young females develop clinically significant disturbance of eating habits and attitudes. ${ }^{48}$ The young person may consider doctors and nurses judgmental and be more inclined to talk openly with an independent person, ie, a psychologist. Alternatively, they may feel there is a stigma attached to seeing a psychologist. Approaches focus on analysis of behavior with behavior modification and/or work on the parent-teen relationship.

Behavior modification may include goal setting, behavioral contracts, and positive reinforcement. In the solutionbased approach, it is usual to start by identifying strengths and abilities that can be drawn upon. ${ }^{49}$ As with adults, the patient's perceptions are all important. Identifying specific abnormal health beliefs or maladaptive coping strategies and aiming to amend them is thus consistent with psychological theory. For example, young children may blame their parents for their diabetes: for taking them to hospital and encouraging doctors and nurses who make them take insulin injections. Anger is often present initially, which can turn to grief that life will never be the same again and that specific ambitions will never be achievable. There may be stigma with children not wanting friends to know that they have diabetes. They may be concerned at how their friends will see them or that they will not be attractive to the opposite sex. Such issues provoke non-cooperation, a form of denial. Interviews aim to explore these factors, counter incorrect perceptions, and generate acceptance and other adaptive coping behaviors.

Coping skills training in adolescence is usually aimed at improving assertiveness and social skills. In a controlled study in adolescents by Marrero et al, group discussion of issues was perceived to be stressful, but coping strategies and role-play exercises produced better psychological functioning. ${ }^{50}$ In a small RCT at summer school, training based on social learning and self-efficacy theory to improve social learning skills and resist peer pressure produced better glycemic control at 4 months compared with controls undergoing group diabetes education. ${ }^{51}$ In an RCT, coping skills training including social problem solving, conflict resolution, and cognitive behavior modification improved metabolic control, self-efficacy, coping, and QoL, which was maintained at 12 months $\left(\mathrm{HbA}_{1 \mathrm{c}} 7.5 \%\right.$ vs $\left.8.5 \%, P=0.001\right)$. Female subjects showed less weight gain and less hypoglycemia. ${ }^{52}$ Mendez and Belendez compared a group program comprising education, discussion of stress and relaxation exercises, 
the concept of self-control, and social skills training with routine care. There was no effect on $\mathrm{HbA}_{1 \mathrm{c}}$, but teenagers reported fewer barriers to adherence, less severity of daily hassles, and better social interaction. ${ }^{53} \mathrm{~A}$ trial of discussion of health-related QoL in adolescents showed that it improved psychosocial parameters. $^{54}$

For young people family functioning is important and has been shown to be associated with glycemic control. ${ }^{55}$ Family disruption or conflict of any sort usually has an adverse effect on metabolic control. The effect on parents of a diagnosis of diabetes in their child is also very substantial and persists. ${ }^{56}$ The effect on siblings should also be considered. Adolescents need to be encouraged to assume increasing responsibility but with mutually agreed parental support and involvement. Without sufficient maturity, youths have worse control. ${ }^{57}$

A systematic review of family interventions identified 13 RCTs in patients $<18$ years of age with a mean reduction in $\mathrm{HbA}_{1 \mathrm{c}}$ of $0.6 \%{ }^{58}$ More recent studies are listed in Table 3. ${ }^{59-69}$ Areas covered by different studies include parent-teen responsibility sharing of diabetes tasks and ways to avoid conflict, discussion of diet, control, planning for social events, practical problem solving, self-management training, and future complications. Information directed at parents covered shared responsibility and behavior analysis: indulgent or democratic, stress management, and how to deal with negative thoughts. Nansel et al achieved a diabetic clinicbased approach with 390 families randomized to receive an approach comprising problem solving, communication skills, and responsibility sharing ("We-Can") over 2 years. A significant improvement in glycemic control was seen in the 12-14 years age group. ${ }^{69}$ The intervention prevented deterioration in glycemic control often seen in adolescents. ${ }^{70}$ Didjurgeit studied older patients with T1DM and the related complications. Weekly problem-focused psychotherapy for 14 weeks improved $\mathrm{HbA}_{1 \mathrm{c}}$ by $0.6 \%{ }^{71} \mathrm{~A}$ parent mentor program has been suggested. ${ }^{72}$

Teamwork is a family intervention concept originally promoted by Anderson et al and assessed in several studies. ${ }^{60,73,74}$ The Families, Adolescents and Children Teamwork Study (FACTS) program in the UK comprised six group sessions facilitated rather than taught, lasting 60-90 minutes monthly with parents involved covering diabetes education, parent-child responsibilities, communication, and conflict resolution skills. In a pilot study, $\mathrm{HbA}_{1 \mathrm{c}}$ reduced by $0.3 \%$ in the treatment group and increased in untreated controls $(P=0.04) .{ }^{66}$ Subsequently, investigators were unable to replicate the earlier results across 10 centers. $^{68}$

Table 3 Recent controlled trials of family therapy in type I diabetes

\begin{tabular}{lllll}
\hline Reference & $\begin{array}{l}\text { Numbers } \\
\text { of subjects }\end{array}$ & $\begin{array}{l}\text { Type } \\
\text { of diabetes }\end{array}$ & $\begin{array}{l}\text { Age } \\
\text { of subjects }\end{array}$ & Intervention \\
\hline Wysocki et a ${ }^{59}$ & 119 & I & $11-17$ years & BFST vs education and support vs current therapy \\
Laffel et a ${ }^{60}$ & 100 & I & $8-17$ years & $\begin{array}{l}\text { Family focused teamwork targeting family involvement } \\
\text { and coping }\end{array}$ \\
Ellis et al ${ }^{61,62}$ & 127 & 1 & $10-17$ years & $\begin{array}{l}\text { Addressed family processes, peer and community } \\
\text { factors }\end{array}$
\end{tabular}

Wysocki et a l63-65 $^{604} \quad$ I $\quad$ 10-18 years $\quad$ BFST-D vs education and support vs current therapy

\begin{tabular}{|c|c|c|c|c|}
\hline Murphy ${ }^{66}$ & 67 & I & $8-16$ years & $\begin{array}{l}\text { Parents and adolescents underwent diabetes skills } \\
\text { training ( } 2 \text { sessions) and family teamwork ( } 2 \text { sessions) }\end{array}$ \\
\hline Harris et al ${ }^{67}$ & 58 & I & $13-18$ years & BFST \\
\hline Murphy et $a^{68}$ & $\begin{array}{l}305 \text { randomized. But } 30 \% \text { did } \\
\text { not attend any training sessions }\end{array}$ & I & $9-17$ years & $\begin{array}{l}\text { Parents and adolescents underwent skills training and } \\
\text { family teamwork }\end{array}$ \\
\hline Nansel et $a^{69}$ & 390 & I & $9-14$ years & $\begin{array}{l}\text { Clinic-based behavioral intervention: problem-solving, } \\
\text { communication skills, and responsibility sharing }\end{array}$ \\
\hline
\end{tabular}


Peer support is a concept that has generated interest recently. Greco et al undertook group sessions of adolescents each with their best friend. Sessions were delivered by a psychologist and included diabetes education, listening skills, problem solving (with peer support), and stress management. Parents reported a decrease in diabetes-related conflict. ${ }^{75}$ It is valuable for parents and their child to gain a better insight into each other's views. Asking parents to simulate diabetes management for 1 week was a novel way of trying to achieve this. ${ }^{76}$

Thus, the emotional response depicted in the self-regulatory model is often seen in young people with diabetes, and maladaptive coping strategies are usually the result. Psychological intervention involves discussions to identify unhelpful perceptions and to move toward acceptance rather than denial. Family therapy involves trying to make use of this important source of social support. Techniques aimed at conflict resolution and "team working" are likely to be helpful. Acceptance and gaining the support of significant others are important adaptive coping behaviors in relation to self-regulatory theory.

\section{Adults with T2DM}

A systematic review of psychological interventions in T2DM identified 12 RCTs. ${ }^{77}$ Nine produced better control.
Worse control occurred in three when compared with (in most trials) education or usual care. The standardized mean effect size was 0.32 , equivalent to a reduction of $0.76 \%$ in $\mathrm{HbA}_{1 \mathrm{c}}$. Most patients had obesity or poor glycemic control but a diverse set of patient groups were studied including individuals with clinical depression or binge eating disorder. Such patients would normally require very different treatments. Thus, it is problematic to analyze their results together. Most studies used CBT or associated strategies such as relaxation techniques, problem solving, contract setting, goal setting, self-monitoring of behavior, and enlisting social support. An exercise to deliver the Diabetes Prevention Program to overweight or obese adults in primary care using coach-led intervention or self-directed DVD use produced weight loss in both groups and controls. ${ }^{78}$ Peer-led ("Expert patient") selfmanagement coaching in newly diagnosed T2DM improved self-efficacy, coping, and saturated fat intake over 6 months. ${ }^{79}$ Peer support has been used in adults in various formats with some success. ${ }^{80}$

Greaves et al conducted a systematic review of interventions to improve diet and physical activity aiming to prevent T2DM. ${ }^{81}$ Interventions to promote dietary change produced clinically meaningful weight loss (3-5 kg at 12 months, $2-3 \mathrm{~kg}$ at 36 months). The majority

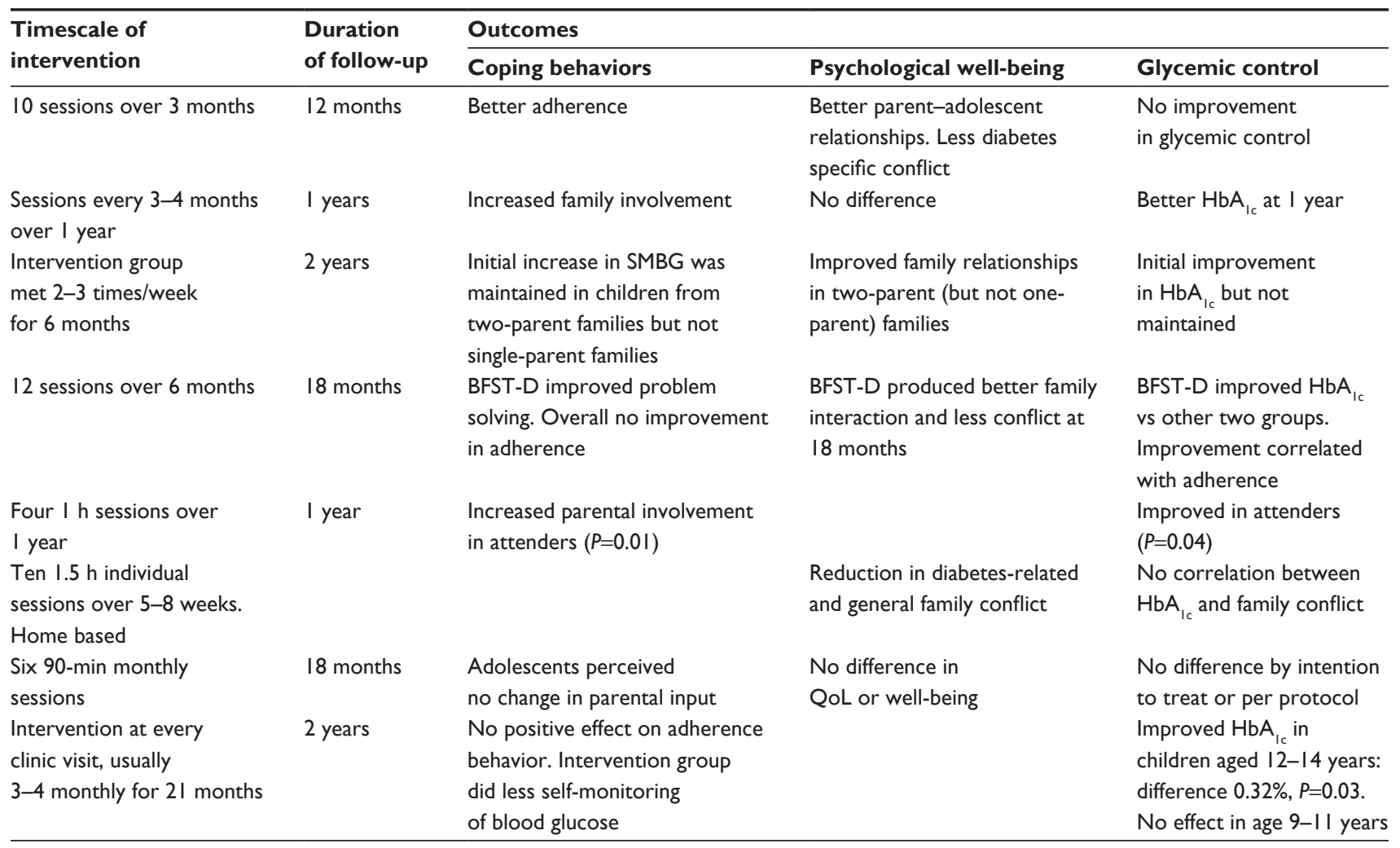


of meta-analyses did find an association between the use of theoretically derived psychosocial intervention and greater weight loss, better change in dietary outcome, and increased physical activity. They used specific goal setting, prompted self-monitoring, feedback on performance, and goal review. Comparison of behavioral intervention plus dietary advice versus dietary advice alone achieved $4.5 \mathrm{~kg}$ weight loss at 6 months. ${ }^{82}$ Social support from family members was particularly effective. ${ }^{83}$ Motivational interviewing is effective for weight loss or combined physical activity and dietary outcome. ${ }^{10}$

\section{Psychoanalytical techniques}

Psychoanalysis is usually a long-term exploratory approach aiming to resolve unconscious conflicts. Psychodynamic therapy is used when problems are unresponsive to reinforcement or reason. Two key concepts are resistance and transference. Resistance might manifest as missing appointments or talking excessively in consultations. Patients transfer their feelings to the therapist. Treatment involves making the unconscious conscious through interpretation leading to recognition. Patients may be encouraged to reenact past events with the therapist to aid interpretation.

In T1DM, psychoanalytic therapy was integrated with CBT to generate new approaches to considering past problems. The therapy helped interpersonal problems, but metabolic control did not improve. ${ }^{84}$ Spiess et al assessed 6 months of therapy (group and individual sessions) in newly diagnosed T1DM. ${ }^{85}$ It generated better adjustment at 9 months but not better glycemic control. In a controlled study, Moran et al used psychoanalytic therapy in children aged 6-18 years with poorly controlled diabetes. Metabolic control improved, and this was maintained at 1 year. ${ }^{86}$

\section{Using new technology to influence self-care behavior}

Adolescent patients in particular will sometimes respond positively to the use of modern technology in their diabetes care. They may relate more to this than they do to diabetes! Patients aged 12-20 years who chose an insulin pump in place of multiple daily injections (MDI) showed sustained improvement in $\mathrm{HbA}_{1 \mathrm{c}}$ over 12 months, better than patients on MDI. The intensive treatment process resulted in improved psychosocial measures in both groups, but those on pumps reported coping with diabetes to be easier. ${ }^{87}$

Educational and psychosocial interventions can be provided by phone, text, email, videoconference, or website. In adolescents none of three RCTs of telephone case management improved $\mathrm{HbA}_{1 \mathrm{c}}$ at 6-7 months. ${ }^{88-90}$ A home-based intensive tailored family program proved better than weekly phone support. ${ }^{91}$ In T2DM, automated phone calls to a Latino population with nurse follow-up improved glycemic control. ${ }^{92,93}$ A program of 14, 30-minute sessions of psychologically based telephone coaching improved self-care behavior, $\mathrm{HbA}_{1 \mathrm{c}}$, and well-being. ${ }^{94}$

A number of groups have tried text messaging to adolescents. A recent systematic review found the overall benefit unclear. ${ }^{95}$ Attempts have been made (in adults) to develop a behavioral model for this intervention. ${ }^{96}$

In an early study, Glasgow et al used individual counseling via computer to assess the barriers to dietary self-care (refer the Health Belief Model) in patients with T1DM and T2DM over age 40 . Follow-up calls were made by research staff. At 12 months, patients maintained improved dietary habits with greater patient satisfaction but not better metabolic control. ${ }^{97}$ Videoconferencing via Skype seems to allow the patient-caregiver relationship to be maintained. ${ }^{98}$ A program of telemedicine case management improved self-efficacy and $\mathrm{HbA}_{1 \mathrm{c}}$ in older diabetic patients with comorbid depression. ${ }^{99}$ A web-based intervention improved the psychosocial well-being of patients aged over $60 .{ }^{100}$ Tang et al used online feedback from nurses. $\mathrm{HbA}_{1 \mathrm{c}}$ was reduced at 6 months but less so after a year. ${ }^{101}$ Thus, the internet can not only be an educational resource but also be an emotional resource for patients. Professionally moderated web-based discussion forums covering nutrition, motivation, and family relationships were reported as improving participants' ability to cope with their diabetes. ${ }^{102}$

Thus, trials investigating the use of new technology to moderate behavior, glycemic control, and well-being have produced some positive data. Intensive programs probably produce better results irrespective of the medium. Web-based systems offer the possibilities for further interventions beyond what has been tried so far.

\section{Conclusion: from theory to practice}

Historically, clinicians have relied on education to achieve optimum self-management by patients. The finding that psychologically based intervention achieves more than didactic education (imparting factual knowledge) is an important one, which underpins the development of behavioral and psychosocial approaches to the management of adherence in routine diabetes care. There is a large body of literature on psychological theory aiming to explain health-related behavior. It is said that intervention needs to be based on theory, meaning attempting to modify the beliefs that lead individuals to behave 
in the way that they do. Few of the interventions listed in this review describe an explicit basis in theory, but nevertheless, such relationships exist. A core process in CBT is the elucidation and challenging of negative thoughts and beliefs. Motivational interviewing elicits patients own views, conflicts, and barriers with the aim of generating more adaptive coping. Empowerment aims to improve patients' perceived personal control over their diabetes, starting with patients' views on barriers and what needs to change. There is considerable overlap between the different approaches.

Drawing conclusions from the literature on psychologically based intervention in diabetes is difficult. More recently, larger RCTs as listed here have been published, but much of the earlier work involved small numbers. Many compared outcome with baseline rather than a controlled design, a fundamental problem in this area of research. Some used waiting list controls or patient choice: those who agreed to participate versus those who would not. Psychological interventions only work for those who engage so this may have some validity. Controlling for session time (attention controls) is important to control for the effect of (any) intervention per se.

Many different interventions have been used. Published descriptions of what was actually done are often limited. What is delivered is likely to be idiosyncratic. Even descriptors such as CBT can include a wide range of approaches. Thus, classification of approaches is problematic. Similarly, a wide range of outcome measures have been used. One review identified 40 different psychosocial outcome measures used in the studies they included, with only five used in more than one RCT. ${ }^{103}$

Meta-analysis has been used to deal with the issues of studies with small numbers. Meta-analysis has shown reductions in $\mathrm{HbA}_{1 \mathrm{c}}$ with psychosocial intervention in T1DM: $-0.48 \%$ in children and $-0.22 \%$ in adults. ${ }^{104}$ In T2DM psychologically based intervention reduced $\mathrm{HbA}_{1 \mathrm{c}}$ by $0.76 \%$ compared with $-0.41 \%,{ }^{105}-0.36 \%,{ }^{106}$ and $-0.43 \%{ }^{107}$ when predominantly educational initiatives were analyzed. In most follow-up studies so far, such influences have not been sustained long-term. Greaves et al and Keen provide summaries of reviews. ${ }^{81,108}$ However, meta-analysis here is problematic owing to the heterogeneous nature of study populations and interventions used. When different interventions are included together it becomes difficult to evaluate which are effective and which will be appropriate for different patients. In many such analyses, the only clear conclusion is that psychologically based intervention is more effective than education alone or "usual care". Thus, we turn back to a more qualitative approach trying to pick out good studies in defined patient groups.
MI seems effective when delivered by a therapist. Training nurses to deliver this approach does not seem to have worked in practice despite a study showing nurses can be trained to an adequate standard. ${ }^{109}$ This has been problematic for attempts to move MI into routine care on a large scale. ${ }^{15,16}$ Even with psychologist therapists, the differences between therapists can be large and can exceed the effect size of the intervention. Outcomes are linked to therapists' skills. The relationship between therapist and subjects influences outcome. ${ }^{110}$ Studies have not so far separated the influence of one therapist versus another.

With adolescents, family-based intervention, work with peers, group work, social skills training, and coping skills produce positive results. Gaining the support of significant others is an important adaptive coping behavior. In addition to established family therapy, the peer group studies are an interesting way of approaching this. Intervention does need to be appropriately targeted. Thus, we find that family therapy produces improved $\mathrm{HbA}_{1 \mathrm{c}}$ in older children but not younger children. ${ }^{69}$ Relationships within the family are likely to be more strained as teenagers get older. Older children have worse control than their younger peers, ${ }^{70}$ so there is more scope to help this group with psychosocial support.

On the basis of studies reviewed here it seems reasonable to expect a reduction of $\sim 0.5 \%$ in $\mathrm{HbA}_{1 \mathrm{c}}$ from psychosocial intervention. The benefit may be greater with targeting of the most appropriate patient groups. But psychologically based interventions require active participation by the patient. In many of the studies listed here agreement to participate was less than $50 \%$ of those approached. Thus, psychologically based management is by no means universally applicable. Nevertheless, most patients with diabetes require training to develop the psychosocial skills to effect behavior change. Behavioral and psychosocial support should be offered to all and become a routine part of diabetic clinic programs. In the UK, currently such support is of limited availability in pediatric clinics and often completely unavailable to adults. Thus, we do not utilize the knowledge we already have. We are in need of assessment routines and simple interventions that we can deliver more widely. Most interventions used in trials were not designed for routine clinical use.

In summary, a variety of behavioral and psychosocial interventions have been trialed. Relationships to psychology theory can be seen. There are sufficient positive results to conclude that these approaches improve metabolic control, although the overall improvements are modest. Targeting specific patient groups is likely to be important. The interventions clearly improve psychosocial outcomes, but the 
results are less strong for glycemic control. More large trials in recent years are improving the evidence base. We are still some way from incorporating these techniques into routine practice despite a clear need.

\section{Disclosure}

The author reports no conflicts of interest in this work.

\section{References}

1. Knight KM, Dornan T, Bundy C. The diabetes educator: trying hard, but must concentrate more on behaviour. Diabet Med. 2006;23(5):485-501.

2. Kahana S, Drotar D, Frazier T. Meta-analysis of psychological interventions to promote adherence to treatment in pediatric chronic health conditions. J Pediatr Psychol. 2008;33(6):590-611.

3. Kulzer B, Hermanns N, Reinecker H, Haak T. Effects of self-management training in type 2 diabetes: a randomized prospective trial. Diabet Med. 2007;24(4):415-423.

4. Harvey JN. Healthbeliefsand healthoutcomes. In:MartinLR,DiMatteoMR, editors. The Oxford Handbook of Health Communication, Behaviour Change and Treatment Adherence. New York: Oxford University Press; 2013:177-192.

5. Hampson SE, Skinner TC, Hart J, et al. Effects of educational and psychosocial interventions for adolescents with diabetes mellitus: a systematic review. Health Technol Assess. 2001;5(10):1-79.

6. Harvey JN, Lawson VL. The importance of health belief models in determining self-care behaviour in diabetes. Diabet Med. 2009;26:5-13.

7. Pouwer F, Ader HJ, Snoek FJ, Heine RJ, van der Ploeg HM. Monitoring of psychological well-being in outpatients with diabetes. Diabetes Care. 2001;24:1929-1935.

8. Rollnick S, Miller WR, Butler CC. Motivational Interviewing in Health Care. 2nd ed. New York: Guilford Press; 2008.

9. Prochaska JO, DiClemente CC. Stages and processes of self-change of smoking: toward an integrative model of change. $J$ Consult Clin Psychol. 1983;51:390-395.

10. Rubak S, Sandbaek A, Lauritzen T, Christensen B. Motivational interviewing: a systematic review and meta-analysis. Br J Gen Pract. 2005;55:305-312.

11. DeLillo V, West DS. Motivational interviewing for weight loss. Psychiatr Clin North Am. 2011;34:861-869.

12. Viner RM, Christie D, Taylor V, Hey S. Motivational/solution-focused intervention improves $\mathrm{HbA}_{1 \mathrm{c}}$ in adolescents with type 1 diabetes: a pilot study. Diabet Med. 2003;20:739-742.

13. Channon SJ, Huws-Thomas MV, Rollnick S, et al. A multicenter randomized controlled trial of motivational interviewing in teenagers with diabetes. Diabetes Care. 2007;30:1390-1395.

14. Nansel T, Ionnotti RJ, Simons-Morton BG, Plotnick LP, Clark LM, Zeitzoff L. Long-term maintenance of treatment outcomes: diabetes personal trainer intervention for youth with type 1 diabetes. Diabetes Care. 2009;32:807-809.

15. Robling M, McNamara R, Bennert K, et al. The effect of the talking diabetes consulting skills intervention on glycaemic control and quality of life in children with type 1 diabetes: cluster randomised controlled trial (DEPICTED study). BMJ. 2012;344:e2359.

16. Christie D, Thompson R, Sawtell M, et al. Structured intensive education maximising engagement, motivation and long term change for children and young people with diabetes: a cluster randomised controlled trial with integral process and economic evaluation - the CASCADE study. Health Technol Assess. 2014;18(20):1-202.

17. West DS, DeLillo V, Bursac Z, Gore SA, Greene PG. Motivational interviewing improves weight loss in women with type 2 diabetes. Diabetes Care. 2007;30:1081-1087.

18. Keogh KM, Smith SM, White P, et al. Psychological family intervention for poorly controlled type 2 diabetes. Am J Manag Care. 2011;17(2):105-113.
19. Gabbay RA, Añel-Tiangco RM, Dellasega C, Mauger DT, Adelman A, Van Horn DH. Diabetes nurse case management and motivational interviewing for change (DYNAMIC): results of a 2-year randomized controlled pragmatic trial. J Diabetes. 2013;5:349-357.

20. Jansink R, Braspenning J, Keizer E, van der Weijden T, Elwyn G, Grol R. No identifiable $\mathrm{HbA}_{\mathrm{lc}}$ or lifestyle change after a comprehensive diabetes programme including motivational interviewing: a cluster randomised trial. Scand J Prim Health Care. 2013;31:119-127.

21. Lakerveld J, Bot SD, Chinapaw MJ, et al. Motivational interviewing and problem solving treatment to reduce type 2 diabetes and cardiovascular disease risk in real life: a randomized controlled trial. Int J Behav Nutr Phys Act. 2013;10:47.

22. Ismail K, Maissi E, Thomas S, et al. A randomized controlled trial of cognitive behaviour therapy and motivational interviewing for people with type 1 diabetes mellitus with persistent sub-optimal glycaemic control: a Diabetes and Psychological Therapies (ADaPT) study. Health Technol Assess. 2010;14(22):1-101; iii-iv.

23. Ridge K, Bartlett J, Cheah Y, et al. Do the effects of psychological treatments on improving glycaemic control in type 1 diabetes persist over time? A long-term follow-up of a randomized controlled trial. Psychosom Med. 2012;74:319-323.

24. Anderson RM, Funnell M, Arnold MS. Using the empowerment approach to help patients change behaviour. In: Anderson BJ, Rubin RR, editors. Practical Psychology for Diabetes Clinicians: How to Deal with the Key Behavioural Issues Faced by Patients and Health-Care Teams. Alexandria, VA, USA: American Diabetes Association; 1996:163-172.

25. Anderson RM, Funnell MM, Butler PM, Arnold MS, Fitzgerald JT, Feste CC. Patient empowerment. Results of a randomized controlled trial. Diabetes Care. 1995;18:943-949.

26. Pibernik-Okanovic M, Prasek M, Pljicanin-Filipovic T, Pavlic-Renar I, Metelko Z. Effects of an empowerment-based psychosocial intervention on quality of life and metabolic control in type 2 diabetic patients. Patient Educ Couns. 2004;52:193-199.

27. Lorig KR, Ritter PL, Gonzalez VM. Hispanic chronic disease self-management: a randomized community-based outcome trial. Nurs Res. 2003;52:361-369.

28. Piatt GA, Anderson RM, Brooks MM, et al. 3-Year follow up of clinical and behavioural improvements following a multifaceted diabetes care intervention: results of a randomized controlled trial. Diabetes Educ. 2010;36:301-309.

29. Tang TS, Funnell MM, Brown MB, Kurlander JE. Self-management support in "real-world" settings: an empowerment-based intervention. Patient Educ Couns. 2010;79:178-184.

30. Howorka K, Pumprla J, Wagner-Nosiska D, Grillmayr H, Schlusche C, Schabmann A. Empowering diabetes out-patients with structured education: short-term and long-term effects of functional insulin treatment on perceived control over diabetes. J Psychosom Res. 2000;48:37-44.

31. Viklund G, Ortqvist E, Wikblad K. Assessment of an empowerment education programme: a randomized study in teenagers with diabetes. Diabet Med. 2007;24:550-556.

32. Rubin RR, Peyrot M, Saudek CD. Effect of diabetes education on self-care, metabolic control, and emotional well-being. Diabetes Care. 1989; 12:673-679.

33. van der Ven NC, Hogenelst MH, Tromp-Wever AM, et al. Short term effects of cognitive behavioural group training (CBGT) in adult type 1 diabetes patients in prolonged poor glycaemic control. A randomised controlled trial. Diabet Med. 2005;22:1619-1623.

34. Snoek FJ, van der Ven NC, Twisk JW, et al. Cognitive behavioural therapy (CBT) compared with blood glucose awareness training (BGAT) in poorly controlled type 1 diabetic patients: long term effects on $\mathrm{HbA}_{1 \mathrm{c}}$ moderated by depression. A randomized controlled trial. Diabet Med. 2008;25:1337-1342.

35. Amsberg S, Anderbro T, Wredling R, et al. A cognitive behaviour therapy-based intervention among poorly controlled adult type 1 diabetes patients - a randomized controlled trial. Patient Educ Couns. 2009;77:72-80. 
36. Karlsen B, Idsoe T, Dirdal I, Rokne Hanestad B, Bru E. Effects of a group based counselling programme on diabetes-related stress, coping, psychological wellbeing and metabolic control in adults with type 1 or type 2 diabetes. Patient Educ Couns. 2004;53(3):299-308.

37. Gregg JA, Callaghan GM, Hayes SC, Glenn-Lawson JL. Improving diabetes self-management through acceptance, mindfulness and values: a randomized controlled trial. J Consult Clin Psychol. 2007; 75(2):336-343

38. Forlani G, Lorusso C, Moscatiello S, et al. Are behavioural approaches feasible and effective in the treatment of type 2 diabetes? A propensity score analysis vs prescriptive diet. Nutr Metab Cardiovasc Dis. 2009;19:313-320.

39. Welschen LMC, van Oppen P, Bot SDM, Kostense PJ, Dekker JM, Nijpels G. Effects of a cognitive behavioural treatment in patients with type 2 diabetes when added to managed care; a randomised controlled trial. J Behav Med. 2013;36:556-566.

40. Snoek FJ, van der Ven NC, Lubach $\mathrm{CH}$, et al. Effects of cognitive behavioural group training (CBGT) in adult patients with poorly controlled insulin-dependent (type 1) diabetes: a pilot study. Patient Educ Couns. 2001;45:143-148.

41. Christie D, Wilson C. CBT in paediatric and adolescent health settings: a review of practice based evidence. Pediatr Rehabil. 2005;8(4):241-247.

42. Surwit RS, van Tilburg MA, Zucker N, et al. Stress management improves long-term glycemic control in type 2 diabetes. Diabetes Care. 2002;25(1):30-34.

43. Hicks C. Comparison of the effects of educating patients' partners on diabetic control. J Inst Health Educ. 1991;29:94-97.

44. Tamez EG, Vacalis TD. Health beliefs, the significant other, compliance with therapeutic regimens among adult Mexican American diabetics. Health Educ. 1989;20:24-31.

45. Wing RR, Marcus MD, Epstein LH, Jawad A. A 'family-based' approach to the treatment of obese type II diabetic patients. $J$ Consult Clin Psychol. 1991;59:156-162.

46. Garcia-Huidobro D, Bittner M, Brahm P, Puschel K. Family intervention to control type 2 diabetes: a controlled clinical trial. Fam Pract. 2011;28:4-11.

47. Kang CM, Chang SC, Chen PL, et al. Comparison of family partnership intervention care vs conventional care in adult patients with poorly controlled type 2 diabetes in a community hospital: a randomized controlled trial. Int J Nurs Stud. 2010;47:1363-1373.

48. Peveler RC, Bryden KS, Neil HA, et al. The relationship of disordered eating habits and attitudes to clinical outcomes in young adult females with type 1 diabetes. Diabetes Care. 2005;28(1):84-88.

49. Christie D, Barnard KD. Supporting resilience and positive outcomes in families, children and adolescents. In: Barnard KD, Lloyd CE, editors. Psychology and Diabetes Care. London: Springer-Verlag; 2012:47-68.

50. Marrero DG, Myers GL, Golden MP, West D, Kershnar A, Lau N. Adjustment to misfortune: the use of a social support group for adolescent diabetics. Pediatr Adolesc Endocrinol. 1982;10:213-218.

51. Kaplan RM, Chadwick MW, Schimmel LE. Social learning intervention to promote metabolic control in type 1 diabetes mellitus: pilot experimental results. Diabetes Care. 1985;8:152-155.

52. Grey M, Boland EA, Davidson M, Li J, Tamborlane WV. Coping skills training for youth with diabetes mellitus has longlasting effects on metabolic control and quality of life. J Pediatr. 2000;137(7):107-113.

53. Mendez FJ, Belendez M. Effects of a behavioural intervention on treatment adherence and stress management in adolescents with IDDM. Diabetes Care. 1997;20:1370-1375.

54. de Wit M, Delemarre-van deWaal HA, Bokma JA, et al. Monitoring and discussing health-related quality of life in adolescents with type 1 diabetes improve psychosocial well-being: a randomized trial. Diabetes Care. 2008;31:1521-1526.

55. Bowes S, Lowes L, Warner J, Gregory JW. Chronic sorrow in parents of children with type 1 diabetes. J Adv Nurs. 2008;65(5):992-1000.
56. Jacobson AM, Hauser ST, Lavori P, et al. Family environment and glycaemic control: a four year prospective study of children and adolescents with insulin dependent diabetes mellitus. Psychosom Med. 1994;56:401-409.

57. Wysocki T, Taylor A, Hough BS, Linscheid TR, Yeates KO, Naglieri JA. Deviation from developmentally appropriate self-care autonomy: association with diabetes outcomes. Diabetes Care. 1996;19:119-125.

58. Armour TA, Norris SL, Jack L, Zhang X, Fisher L. The effectiveness of family interventions in people with diabetes mellitus: a systematic review. Diabet Med. 2005;22:1295-1305.

59. Wysocki T, Greco P, Harris MA, Bubb J, White NH. Behavior therapy for families of adolescents with diabetes: maintenance of treatment effects. Diabetes Care. 2001;24:441-446.

60. Laffel LM, Vangsness L, Connell A, Goebel-Fabbri A, Butler D, Anderson BJ. Impact of ambulatory, family-focused teamwork intervention on glycemic control in youth with type 1 diabetes. J Pediatr. 2003;142:409-416.

61. Ellis D, Frey M, Naar-King S, Templin T, Cunningham P, Cakan N. Use of multisystemic therapy to improve regimen adherence among adolescents with type 1 diabetes in chronic poor metabolic control: a randomized controlled trial. Diabetes Care. 2005;28(7):1604-1610.

62. Ellis DA, Templin T, Naar-King S, et al. Multisystemic therapy for adolescents with poorly controlled type 1 diabetes: stability of treatment effects in a randomized controlled trial. J Consult Clin Psychol. 2007;75:168-174

63. Wysocki T, Harris MA, Buckloh LM, et al. Effects of behavioural family systems therapy for diabetes on adolescents' family relationships, treatment adherence, and metabolic control. J Pediatr Psychol. 2006;31:928-938.

64. Wysocki T, Harris MA, Buckloh LM, et al. Randomized trial of behavioural family systems therapy for diabetes: maintenance of effects on diabetes outcomes in adolescents. Diabetes Care. 2007;30:555-560.

65. Wysocki T, Harris MA, Buckloh LM, et al. Randomized, controlled trial of behavioural family systems therapy for diabetes: maintenance and generalization of effects on parent-adolescent communication. Behav Ther. 2008;39:33-46.

66. Murphy HR, Wadham C, Rayman G, Skinner TC. Approaches to integrating paediatric diabetes care and structured education: experiences from the families, adolescents and children's teamwork study (FACTS). Diabet Med. 2007;24:1261-1268.

67. Harris MA, Freeman KA, Beers M. Family therapy for adolescents with poorly controlled diabetes: initial test of clinical significance. J Pediatr Psychol. 2009;34:1097-1107.

68. Murphy HR, Wadham C, Hassler-Hurst J, Rayman G, Skinner TC, Families and Adolescents Communication and Teamwork Study (FACTS) Group. Randomized trial of a diabetes self-management education and family teamwork intervention in adolescents with type 1 diabetes. Diabet Med. 2012;29:e249-e254.

69. Nansel TR, Iannotti RJ, Liu A. Clinic-integrated behavioral intervention for families of youth with type 1 diabetes: randomized clinical trial. Pediatrics. 2012;129(4):e866-e873.

70. O'Hagan M, Harvey JN, for the Brecon Group. Glycemic control in children with type 1 diabetes in Wales. Diabetes Care. 2010;33(8):1724-1726.

71. Didjurgeit U, Kruse J, Schmitz N, Stuckenschneider P, Sawicki P. A time-limited, problem-orientated psychotherapeutic intervention in type 1 diabetic patients with complications: a randomised controlled trial. Diabet Med. 2002;19(10):814-821.

72. Sullivan-Bolyai S, Bova C, Leung K, Trudeau A, Lee M, Gruppuso P. Social support to empower parents (STEP): an intervention for parents of young children newly diagnosed with type 1 diabetes. Diabetes Educ. 2010;36:88-97.

73. Anderson BJ, Brackett J, Ho J, Laffel L. An office-based intervention to maintain parent-adolescent teamwork in diabetes management: impact on parent involvement, family conflict, and subsequent glycemic control. Diabetes Care. 1999;22:713-721. 
74. Svoren B, Butler D, Levine B, Anderson BJ, Laffel L. Reducing acute adverse outcomes in youths with type 1 diabetes: a randomized controlled trial. Pediatrics. 2003;112:914-922.

75. Greco P, Sroff Pendley J, McDonnell K, Reeves G. A peer group intervention for adolescents with type 1 diabetes and their best friends. $J$ Pediatr Psychol. 2001;26:485-490.

76. Satin W, LaGreca AM, Zigo MA, Skyler JS. Diabetes in adolescence: effects of multifamily group intervention and parent simulation of diabetes. J Pediatr Psychol. 1989;14:259-275.

77. Ismail K, Winkley K, Rabe-Hesketh S. Systematic review and metaanalysis of randomised controlled trials of psychological interventions to improve glycaemic control in patients with type 2 diabetes. Lancet. 2004;363:1589-1597.

78. Ma J, Yank V, Xiao L, et al. Translating the diabetes prevention program lifestyle intervention for weight loss into primary care: a randomized trial. JAMA Intern Med. 2013;173:113-121.

79. Van der Wulp I, de Leeuw JR, Gorter KJ, Rutten GE. Effectiveness of peer-led self-management coaching for patients recently diagnosed with type 2 diabetes mellitus in primary care: a randomized controlled trial. Diabet Med. 2012;29:e390-e397.

80. Dale JR, Williams SM, Bowyer V. What is the effect of peer support on diabetes outcomes in adults? A systematic review. Diabet Med. 2012;29:1361-1377.

81. Greaves CJ, Sheppard KE, Abraham C, IMAGE Study Group, et al. Systematic review of reviews of intervention components associated with increased effectiveness in dietary and physical activity interventions. BMC Public Health. 2011;11:119.

82. Shaw K, Rourke P, Del M, Kenardy J. Psychological interventions for overweight or obesity. Cochrane Database Syst Rev. 2005;(2):CD003818.

83. Avenell A, Broom J, Brown TJ, et al. Systematic review of the long-term effects and economic consequences of treatments for obesity and implications for health improvement. Health Technol Assess. 2004;8(21):1-194.

84. Fosbury J, Bosley CM, Ryle A, Sonksen P, Judd S. A trial of cognitive analytical therapy in poorly controlled type 1 patients. Diabetes Care. 1997;20:959-964.

85. Spiess K, Sachs G, Pietschmann P, Prager R. A program to reduce onset distress in unselected type 1 diabetic patients: effects on psychological variables and metabolic control. Eur J Endocrinol. 1995;132:580-586.

86. Moran G, Fonagy P, Kurtz A, Bolton A, Brook C. A controlled study of psychoanalytic treatment of brittle diabetes. J Am Acad Child Adolesc Psychiatry. 1991;30(6):926-935.

87. Boland EA, Grey M, Oesterle AL, Frederickson L, Tamborlane WV. Continuous subcutaneous insulin infusion: a new way to lower risk of severe hypoglycaemia, improve metabolic control, and enhance coping in adolescents with type 1 diabetes. Diabetes Care. 1999;22: 1779-1784.

88. Howe CJ, Jawad AF, Tuttle AK, et al. Education and telephone case management for children with type 1 diabetes: a randomized controlled trial. J Pediatr Nurs. 2005;20:83-95.

89. Lawson ML, Cohen N, Richardson C, Orrbine E, Pham B. A randomized trial of regular standardized telephone contact by a diabetes nurse educator in adolescents with poor diabetes control. Pediatr Diabetes. 2005;6:32-40.

90. Nunn E, King B, Smart C, Anderson D. A randomized controlled trial of telephone calls to young patients with poorly controlled type 1 diabetes. Pediatr Diabetes. 2006;7:254-259.

91. Ellis DA, Naar-King S, Chen X, Moltz K, Cunningham PB, Idalski-Carcone A. Multisystemic therapy compared to telephone support for youth with poorly controlled diabetes: findings from a randomized controlled trial. Ann Behav Med. 2012;44:207-215.
92. Piette JD, Weinberger M, McPhee S. The effect of automated calls with telephone nurse follow-up on patient centered outcomes of diabetes care: a randomized controlled trial. Med Care. 2000;38:218-230.

93. Piette JD, Weinberger M, McPhee S, Mah CA, Kraemer FB, Crapo LM. Do automated calls with nurse follow-up improve selfcare and glycaemic control among vulnerable patients with diabetes? Am J Med. 2000;208:20-27.

94. Wolever RQ, Dreusicke M, Fikkan J, et al. Integrative health coaching for patients with type 2 diabetes: a randomized clinical trial. Diabetes Educ. 2010;36:629-639.

95. Herbert L, Owen V, Pascarella L, Streisand R. Text message interventions for children and adolescents with type 1 diabetes: a systematic review. Diabetes Technol Ther. 2013;15:362-370.

96. Nundy S, Dick JJ, Solomom MC, Peek ME. Developing a behavioral model for mobile phone-based diabetes interventions. Patient Educ Couns. 2013;90:125-132.

97. Glasgow RE, LaChance PA, Toobert DJ, Brown J, Hampson SE, Riddle MC. Long-term effects and costs of brief behavioural dietary intervention for patients with diabetes delivered from the medical office. Patient Educ Couns. 1997;32:175-184.

98. Freeman KA, Duke DC, Harris MA. Behavioral health care for adolescents with poorly controlled diabetes via Skype: does working alliance remain intact? J Diabetes Sci Technol. 2013;7:727-735.

99. Trief PM, Eimicke JP, Teresi JA, et al. Psychosocial outcomes of telemedicine case management for elderly patients with diabetes. Diabetes Care. 2007;30:1266-1268.

100. Bond GE, Burr RL, Wolf FM, Feldt K. The effects of a web-based intervention on psychosocial well-being among adults aged 60 and older with diabetes: a randomized trial. Diabetes Educ. 2010;36:446-456.

101. Tang PC, Overhage JM, Chan AS, et al. Online disease management of diabetes: engaging and motivating patients online with enhanced resources-diabetes (EMPOWER-D), a randomized controlled trial. J Am Med Inform Assoc. 2013;20:526-534.

102. Zrebiec J, Jacobson AM. What attracts patients with diabetes to an internet support group? A 21-month longitudinal website study. Diabet Med. 2001;18:154-158.

103. Murphy HR, Rayman G, Skinner TC. Psycho-educational interventions for children and young people with type 1 diabetes. Diabet Med. 2006;23:935-943.

104. Winkley K, Landau S, Eisler I, Ismail K. Psychological interventions to improve glycaemic control in patients with type 1 diabetes: systematic review and meta-analysis of randomised controlled trials. BMJ. 2006;333:65-68.

105. Padgett D, Mumford E, Hynes M, Carter R. Meta-analysis of the effects of educational and psychosocial interventions on management of diabetes mellitus. J Clin Epidemiol. 1988;41:1007-1030.

106. Brown SA. Studies of educational interventions and outcomes in diabetic adults: a meta-analysis revisited. Patient Educ Couns. 1990;16:189-215.

107. Gary TL, Genkinger JM, Guallar E, Peyrot M, Brancati FL. Meta-analysis of randomized educational and behavioural interventions in type 2 diabetes. Diabetes Educ. 2003;29:488-501.

108. Keen A. Which psychological interventions work? JR Coll Physicians Edinb. 2010;40(Suppl 17):20-24.

109. Maissi E, Ridge K, Treasure J, et al. Nurse-led psychological interventions to improve diabetes control: assessing competencies. Patient Educ Couns. 2011;84:e37-e43.

110. Beutler LE, Malik M, Alimobamed S, et al. Therapist variables. In: Lambert MJ, editor. Bergin and Garfield's Handbook of Psychotherapy and Behaviour Change. 5th ed. New York: John Wiley; 2004:227-306.

111. Lehmkuhl HD, Storch EA, Cammarata C, et al. Telehealth behaviour therapy for the management of type 1 diabetes in adolescents. J Diabetes Sci Technol. 2010;4:199-208. 
Diabetes, Metabolic Syndrome and Obesity: Targets and Therapy

Dovepress

\section{Publish your work in this journal}

Diabetes, Metabolic Syndrome and Obesity: Targets and Therapy is opinion and commentaries are all considered for publication. The an international, peer-reviewed open-access journal committed to the rapid publication of the latest laboratory and clinical findings in the fields of diabetes, metabolic syndrome and obesity research Original research, review, case reports, hypothesis formation, expert manuscript management system is completely online and includes a very quick and fair peer-review system, which is all easy to use. Visit $\mathrm{http}: / / \mathrm{www}$.dovepress.com/testimonials.php to read real quotes from published authors.

Submit your manuscript here: http://www.dovepress.com/diabetes-metabolic-syndrome-and-obesity-targets-and-therapy-journal 